\title{
miR-125b develops chemoresistance in Ewing sarcoma/primitive neuroectodermal tumor
}

\author{
Keiichiro lida', Jun-ichi Fukushi ${ }^{*}$, Yoshihiro Matsumoto ${ }^{1}$, Yoshinao Oda², Yusuke Takahashi ${ }^{2}$, Toshifumi Fujiwara', \\ Yuko Fujiwara-Okada ${ }^{1}$, Mihoko Hatano $^{1}$, Akira Nabashima', Satoshi Kamura ${ }^{1}$ and Yukihide Iwamoto'
}

\begin{abstract}
Background: Diverse functions of microRNAs (miRNAs), including effects on tumorigenesis, proliferation, and differentiation, have been reported, and several miRNAs have also been demonstrated to play an important role in apoptosis. In this study, we investigated the possible role that miRNAs may play in the development of chemoresistance in Ewing sarcoma/primitive neuroectodermal tumor (EWS).

Methods: We screened doxorubicin (Dox)-resistant EWS cells to identify any distinct miRNA sequences that may regulate the chemoresistance of EWS cells. The effects of miRNAs were evaluated using a chemosensitivity assay. The possible target genes of the miRNAs were predicted using a web-based prediction program.

Results: We found miR-125b to be upregulated in two different Dox-resistant EWS cell lines. The upregulation of miR-125b was also confirmed in the EWS tumors having survived chemotherapy regimen which includes doxorubicin. When miR-125b was knocked down in EWS cells, both the Dox-resistant and parental cells showed an enhanced sensitivity to doxorubicin, which was associated with the upregulation of the pro-apoptotic molecules, p53 and Bak. Inversely, the overexpression of miR-125b in parental EWS cells resulted in enhanced drug resistance, not only to doxorubicin, but also to etoposide and vincristine.
\end{abstract}

Conclusions: Our findings suggest that miR-125b may play a role in the development of chemoresistance in EWS by suppressing the expression of the apoptotic mediators, such as p53 and Bak.

Keywords: Ewing sarcoma/primitive neuroectodermal tumor, miR-125b, p53, Bak, Chemoresistance

\section{Background}

The Ewing sarcoma/primitive neuroectodermal tumor (EWS) is a malignant small round cell tumor of the bone and soft tissues, and ranks second in frequency among primary bone tumors in children and adolescents. EWS is aggressive, and is associated with the most unfavorable prognosis of all primary musculoskeletal tumors [1]. With the development of multimodal therapeutic regimens that include chemotherapy, irradiation, and surgery, long-term survival has been achieved for approximately $70 \%$ of patients with localized disease [2]. However, smaller improvements have been observed for patients with recurrent disease, largely because their tumors are resistant to chemotherapy [3-6].

\footnotetext{
* Correspondence: fukushi@med.kyushu-u.ac.jp

${ }^{1}$ Department of Orthopaedic Surgery, Graduate School of Medical Sciences, Kyushu University, Maidashi3-1-1, Fukuoka 812-8582, Japan

Full list of author information is available at the end of the article
}

Several different mechanisms of chemoresistance in cancer have been elucidated. Enhanced drug-efflux pump activity, changes in the intracellular metabolic machinery, upregulation of DNA repair mechanisms, induction of growth signaling, and impairment of apoptosis can all lead to the acquisition of drug resistance [7]. In EWS, insulinlike growth factor [8,9], c-kit [10,11], CD99 [12], CD133 [13], and p53 [14] have been reported to modulate the anti-tumor effects of chemotherapy. We have previously reported that P-glycoprotein (P-gp) and MRP1 were overexpressed in doxorubicin (Dox)-resistant EWS cells, and the cells treated with P-gp and MRP inhibitors showed improved sensitivity to various drugs $[15,16]$.

In addition to the above mechanisms, recent studies have focused on the involvement of microRNA (miRNA) during the acquisition of chemoresistance in cancer. The miRNAs are small endogenous non-coding RNAs that downregulate gene expression mainly by binding to the 
3'UTR of the target gene region [17]. Their diverse functions, including effects on tumorigenesis, proliferation, differentiation, and apoptosis have been reported [18], and several miRNAs have been shown to have an important role in the development of chemoresistance [19]. Very recently, miR-34a was reported to regulate the chemosensitivity of EWS cells and to be a prognostic marker [20].

In the present study, we screened Dox-resistant EWS cells for distinct miRNA sequences that may regulate the chemosensitivity of EWS cells. Among 46 miRNAs, miR-125b was commonly upregulated in two different Dox-resistant cell lines. The upregulation of miR-125b was also confirmed in the EWS tumors having survived chemotherapy regimen which includes doxorubicin. We demonstrate that miR-125b promotes multidrug resistance by suppressing the expression of two apoptotic mediators, p53 and Bak. Further, our observations indicate that the miR-125b-p53/Bak pathway plays a role during the acquisition of Dox-resistance, and may potentially serve as a therapeutic target for EWS.

\section{Results}

miR-125b enhances the chemoresistance of EWS cells to doxorubicin

We examined the expression of miRNAs in Dox-resistant EWS cells (VH-64/ADR) using the Luminex multiplex assay system, and compared the results with those observed in the parental VH-64 cells. Among the 46 different miRNAs examined, miR-125b was the most highly upregulated miRNA in the VH-64/ADR cells compared to the parental cells (Figure 1A). The upregulation of miR$125 \mathrm{~b}$ in the resistant cells was then confirmed by quantitative RT-PCR (the expression was 1.6-fold higher than that of the parental cells) (Figure 1B). The upregulation of miR-125b was also observed in another Dox-resistant EWS cell line, WE-68/ADR (also 1.6-fold higher than the parental WE-68 cells) (Figure 1B).

We were interested whether miR-125b was expressed in human EWS tumors. We examined five EWS tumor sample pairs, consisting of samples collected before and after chemotherapy using a VDC-IE (vincristine, doxorubicin, cyclophosphamide, ifosfamide, and etoposide) or VAIA (vincristine, actinomycin D, ifosfamide, and doxorubicin) regimen. The expression levels of miR-125b were significantly upregulated in the resection samples consisting of viable tumor cells after chemotherapy (Figure 1C). The common upregulation of miR-125b in two different Doxresistant cells, as well as in the clinical EWS tumor cells having survived chemotherapy, suggests that miR-125b may be involved in the acquisition of Dox-resistance in EWS cells.

We next examined whether miR-125b could modulate the chemosensitivity to doxorubicin in EWS cells. When
miR-125b was knocked down in the Dox-resistant cell lines, significantly enhanced cell death was observed (Figure 2A). The IC50 value shifted from 2570 to $1480 \mathrm{ng} /$ $\mathrm{ml}$ in the VH-64/ADR cells, and from 188 to $96 \mathrm{ng} / \mathrm{ml}$ in the WE-68/ADR cells. The increased sensitivity to doxorubicin was also observed in parental cells after downregulating miR-125b (Figure 2B, from $21.8 \mathrm{ng} / \mathrm{ml}$ to $12.0 \mathrm{ng} / \mathrm{ml}$ in VH-64 cells, and from 13.6 to $7.0 \mathrm{ng} / \mathrm{ml}$ in WE-68 cells). The enhanced sensitivity to doxorubicin induced by downregulating miR-125b was also observed in three other EWS cell lines, RD-ES, SK-ES, and TC-71 (Additional file 1: Figure S1). To demonstrate the effect of miR-125b was not off-target, we also knocked down miR-93 which was about 1.5 times upregulated in Doxresistance cells (Figure 1A). Down-regulating miR-93 induced no significant changes in the chemosensitivity to doxorubicin in EWS cells (Figure 2B). In contrast, when miR125b was overexpressed in the parental cells, significantly less cell death was induced by doxorubicin (Figure 2C). The IC50 values shifted from 21.8 to $26.7 \mathrm{ng} /$ $\mathrm{ml}$ in the VH-64 cells, and from 8.1 to $12.6 \mathrm{ng} / \mathrm{ml}$ in the WE-68 cells. These results indicate that miR-125b enhances the chemoresistance of EWS cells to doxorubicin.

\section{miR-125b downregulates the pro-apoptotic molecules, p53 and Bak}

We have previously reported that drug-efflux pump was overexpressed in Dox-resistance cells and developed chemoresisitance [16]. An immunoblot assay revealed no changes in P-gp in the Dox-resistant cells after downregulating miR-125b (Figure $3 \mathrm{~A}$ ). Since miR-125b can affect chemosensitivity in the parental cells (Figure 2B) where efflux pumps were almost undetectable (Figure 3A) [16], additional mechanisms are likely to be involved in miR-125b-related chemosensitivity. In addition to drug efflux pumps, the induction of apoptosis is one of the most important mechanisms by which various anti-cancer drugs, including doxorubicin, exert their therapeutic effects [21]. Therefore, we investigated whether miR-125b can modulate apoptosis. When parental EWS cells were treated with doxorubicin, cleavage of caspase 3 was induced, indicating the induction of apoptotic cell death (Figure 3B). The enhanced cleavage of caspase 3 was quantitatively confirmed by ELISA (Figure 3C). When miR-125b was stably downregulated, enhanced cleavage of caspase 3, along with enhanced cell death (Figure 2B), was induced upon doxorubicin treatment (Figures 3B, C). This suggests that miR-125b may modulate chemoresistance by regulating apoptosis.

To elucidate the mechanism underlying how miR$125 \mathrm{~b}$ regulates apoptosis, we sought the target gene(s) of miR-125b by using the web-based prediction program, TargetScan (http://www.targetscan.org/). Among the various predicted target genes, we focused on p53 and Bak, 


A Relative miRNA expression in VH-64/ADR
\begin{tabular}{|c|c|c|c|c|c|c|c|}
\hline$\leqq 1.5$ & miR-125b(1.7) & \multicolumn{2}{|c|}{ let-7c(1.6) } & miR-93(1.5) & \\
\hline \multirow{3}{*}{$1 \sim 1.5$} & let-7a & miR-16 & miR-181b & miR-34a & miR-185 & miR-20a & let-7g \\
\cline { 2 - 8 } & miR-10a & miR-210 & let-7i & miR-205 & miR-27a & miR-29c & miR-136 \\
\cline { 2 - 8 } & miR-182 & miR-138 & miR-95 & miR-96 & miR-30d & miR-24-2 & miR-21 \\
\hline \multirow{3}{*}{$0.7 \sim 1$} & miR-106a & miR-34b & miR-29b-2 & miR-200b & miR-17 & miR-372 & miR-218 \\
\cline { 2 - 8 } & miR-195 & miR-137 & miR-9 & miR-125a-5a & miR-141 & miR-221 & miR-212 \\
\cline { 2 - 8 } & miR-29a & miR-100 & miR-10b & miR-135a & miR-23b & & \\
\hline
\end{tabular}

The miRNAs are listed in descending order
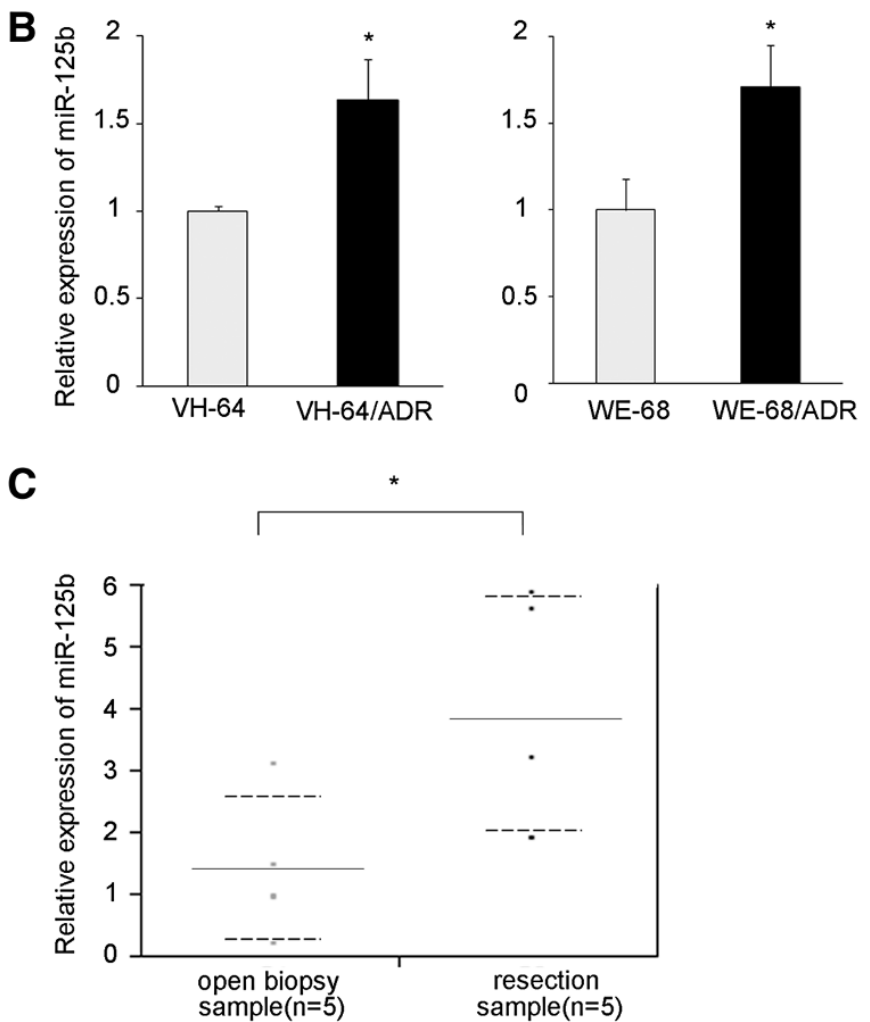

Figure 1 The miRNA expression levels in Dox-resistant EWS cells. A) The relative miRNA expression in Dox-resistant VH-64/ADR compared to parental VH-64 cells. The 46 miRNAs are listed in descending order. B) qRT-PCR was performed to confirm the differences in the expression of miR-125b in two different Dox-resistant cell lines. RNU6B was used as an internal control. The data represent the means of three separate experiments. The results are the means $\pm S D$. ${ }^{*}, P<0.05$. C) qRT-PCR was performed to confirm the differences in the expression of miR-125b in EWS tumors before and after treatment. A comparison was made between the EWS tumors before (open biopsy sample) and after (resection sample) VDC-IE or VAIA chemotherapy. RNU6B was used as an internal control. The gene expression levels were normalized to the average miR-125b expression level of the open biopsy samples. The results are given as the means (solid lines) \pm SD (dashed lines). *, $\mathrm{P}<0.05$.

because they are involved in apoptotic signaling. In addition, both p53 and Bak have been reported to be direct targets of miR-125b in other types of cancer [22-25]. An immunoblot assay revealed that the expression levels of p53 and Bak were upregulated when miR-125b was stably knocked down in the parental EWS cells (Figure 3D), indicating that miR-125b suppressed these apoptotic mediators.

To validate the binding of miR-125b to the 3 'UTR of p53 and Bak, we performed a luciferase reporter assay. Consistent with the findings of previous reports [22-25], the ectopic expression of miR-125b suppressed the activity of luciferase construct containing the 3'UTR of p53 and Bak (Additional file 2: Figure S2). These observations indicate that miR-125b directly targets p53 and Bak in EWS cells.

We then examined the roles of p53 and Bak in Doxinduced cell death. The p53 protein has been reported to sensitize EWS Rh1 cells to doxorubicin [14]. Bak is a relatively novel pro-apoptotic gene of the Bcl-2 family, and is known to mediate Dox-induced apoptosis in myeloma and lymphoma cell lines [26]. When p53 was knockeddown, both the VH-64 and WE-68 parental cells showed significant resistance to Dox-treatment (Figure 4A). The 

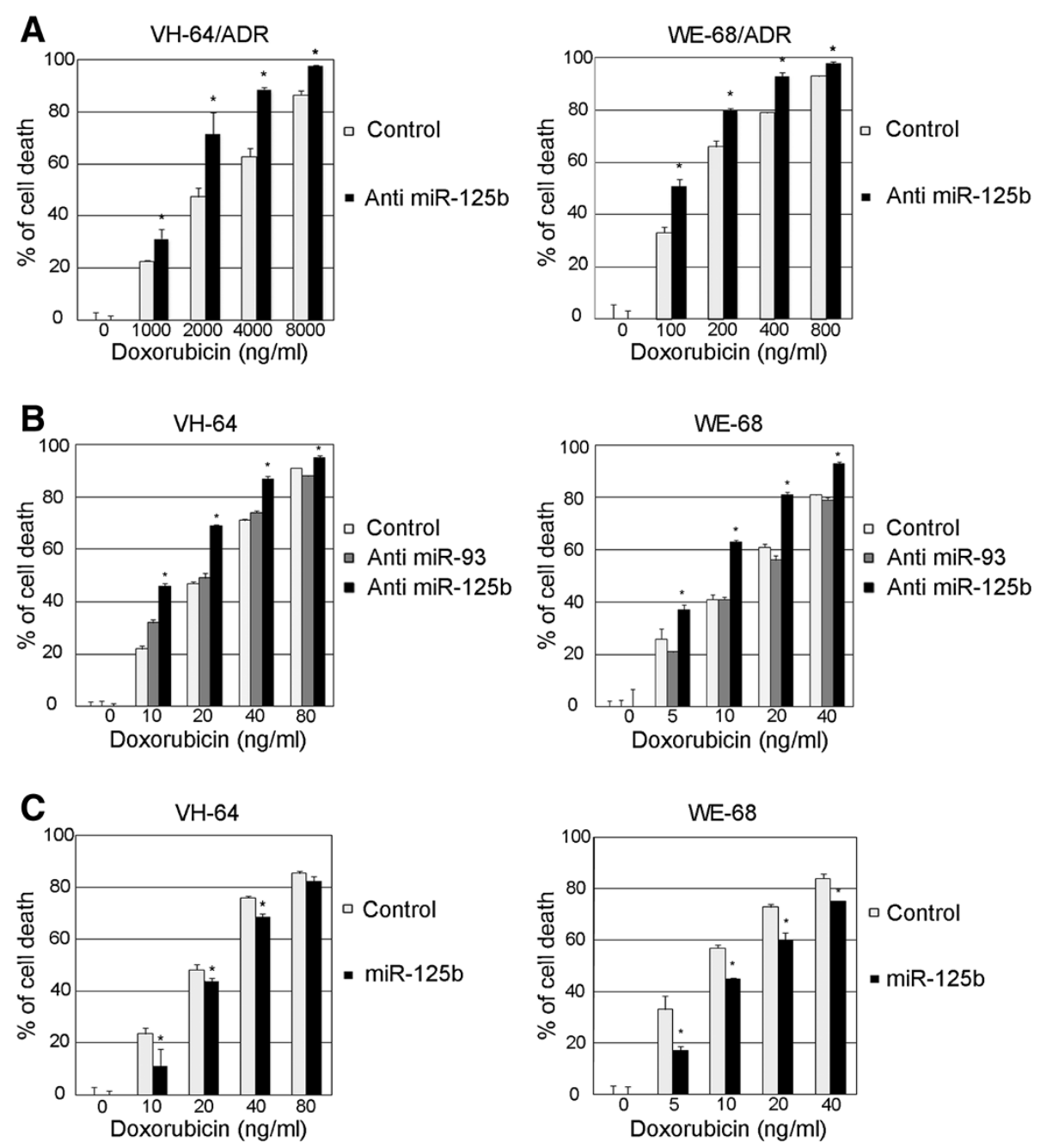

Figure 2 The effects of miR-125b on the Dox-induced cytotoxicity in EWS cells. An antisense (miR-125b and miR-93) or control construct was introduced into the Dox-resistant cells $\mathbf{A}$ ), and the parental cells $\mathbf{B}$ ) using a lentivirus. The cells were cultured with puromycin for 2 weeks to ensure a stable knockdown, and then were seeded at $2 \times 10^{3}$ cells/well in 96 well plates. Twelve hours later, the cells were treated with various concentrations of doxorubicin for an additional $48 \mathrm{~h}$. The cell viability was detected by the CellTiter-GloTM Luminescent Cell Viability Assay. The data represent the means of three separate experiments. The results are the means \pm SD. ${ }^{*}, \mathrm{P}<0.05$. C) Cells were seeded at $2 \times 10^{3}$ cell/well in 96 well plates $36 \mathrm{~h}$ after transfection with $100 \mathrm{nM}$ control or has-miR-125b miRNA Precursor. The cells were treated with various concentrations of doxorubicin for an additional $48 \mathrm{~h}$. The cell viability was detected by the CellTiter-GloTM Luminescent Cell Viability Assay. The data represent the means of three separate experiments. The results are the means \pm SD. ${ }^{*}, \mathrm{P}<0.05$.

IC50 values shifted from 17.9 to $33.3 \mathrm{ng} / \mathrm{ml}$ in the $\mathrm{VH}-64$ cells, and from 9.4 to $16.7 \mathrm{ng} / \mathrm{ml}$ in the WE-68 cells. In contrast, when Bak was knocked down in either VH-64 or WE-68 cells, no significant changes were observed in the Dox-related cytotoxicity (Figure 4B).

We were interested in determining whether miR-125b could modulate the chemosensitivity in an EWS cell line expressing a truncated p53 mutant, SK-N-MC [27]. When miR-125b was knocked down in the cell, significantly enhanced cell death was observed upon Dox-treatment (the IC50 value shifted from 11.0 to $8.4 \mathrm{ng} / \mathrm{ml}$ ), and the expression level of Bak was significantly enhanced (Figure 5A). When Bak was knocked down in the SK-N-MC cell line, the cells showed significant resistance to Dox-treatment (Figure 5B). In contrast, when p53 and Bak were overexpressed, the cells showed significant sensitivity to doxorubicin (Figure $5 \mathrm{C}$ ). These results suggest that miR-125b enhances chemoresistance by downregulating the p53/Bak apoptotic pathway in EWS cells.

miR-125b regulates multidrug resistance in EWS cells We have previously reported that Dox-resistant EWS cells expressed P-gp and MRP1, and showed crossresistance to histone deacetylase inhibitors [16]. Because the VDC-IE protocol has been accepted as a standard 

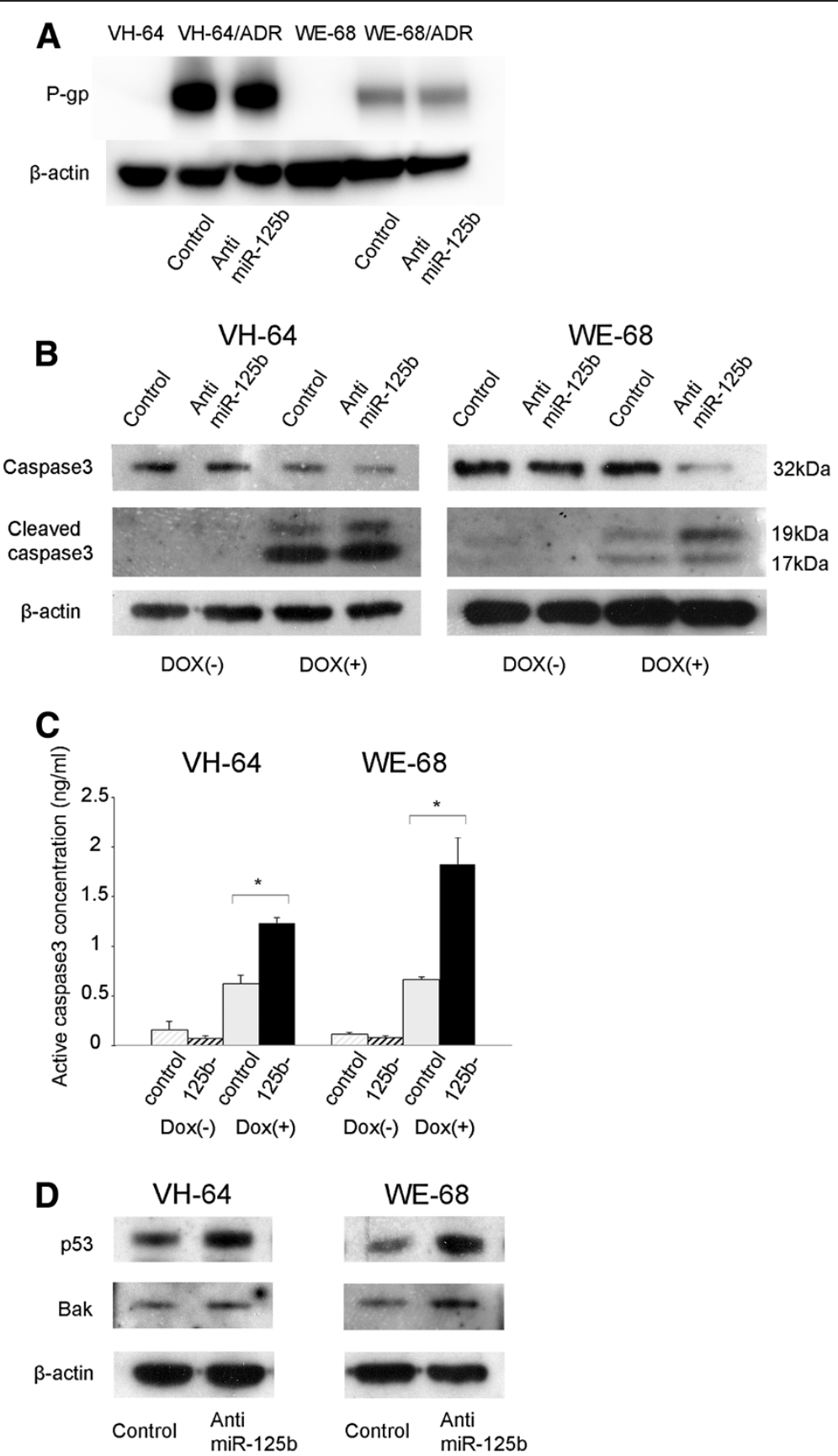

Figure 3 Suppression of the expression of p53 and Bak by miR-125b. A) miR-125b was stably knocked down in Dox-resistant EWS cells, and the whole cell lysates were subjected to an immunoblot analysis using antibodies against P-gp and $\beta$-actin. B), C) miR-125b was stably knocked down in EWS cells, and the cells were incubated with or without $100 \mathrm{ng} / \mathrm{ml}$ of doxorubicin for $24 \mathrm{~h}$. The whole cell lysates were subjected to an immunoblot analysis using antibodies against caspase 3, cleaved caspase 3, and $\beta$-actin (B). The active caspase 3 levels were quantitated by using ELISA (C). D) miR-125b was stably knocked down in EWS cells, and the whole cell lysates were subjected to an immunoblot analysis using antibodies against p53, Bak, and $\beta$-actin.

regimen for treating EWS [28], we wanted to determine whether miR-125b could modulate the sensitivity to the above drugs. Among the 5 drugs in the standard regimen, cyclophosphamide and ifosfamide were not investigated because they are prodrugs, and cannot be evaluated in in vitro studies. Instead, we used mafosfamide, a preactivated cyclophosphamide analog, as a subsutitute for cyclophosphamide. As shown in Figure 6, Dox-resistant cells showed significant cross-resistance to vincristine and etoposide. The downregulation of miR-125b in the 

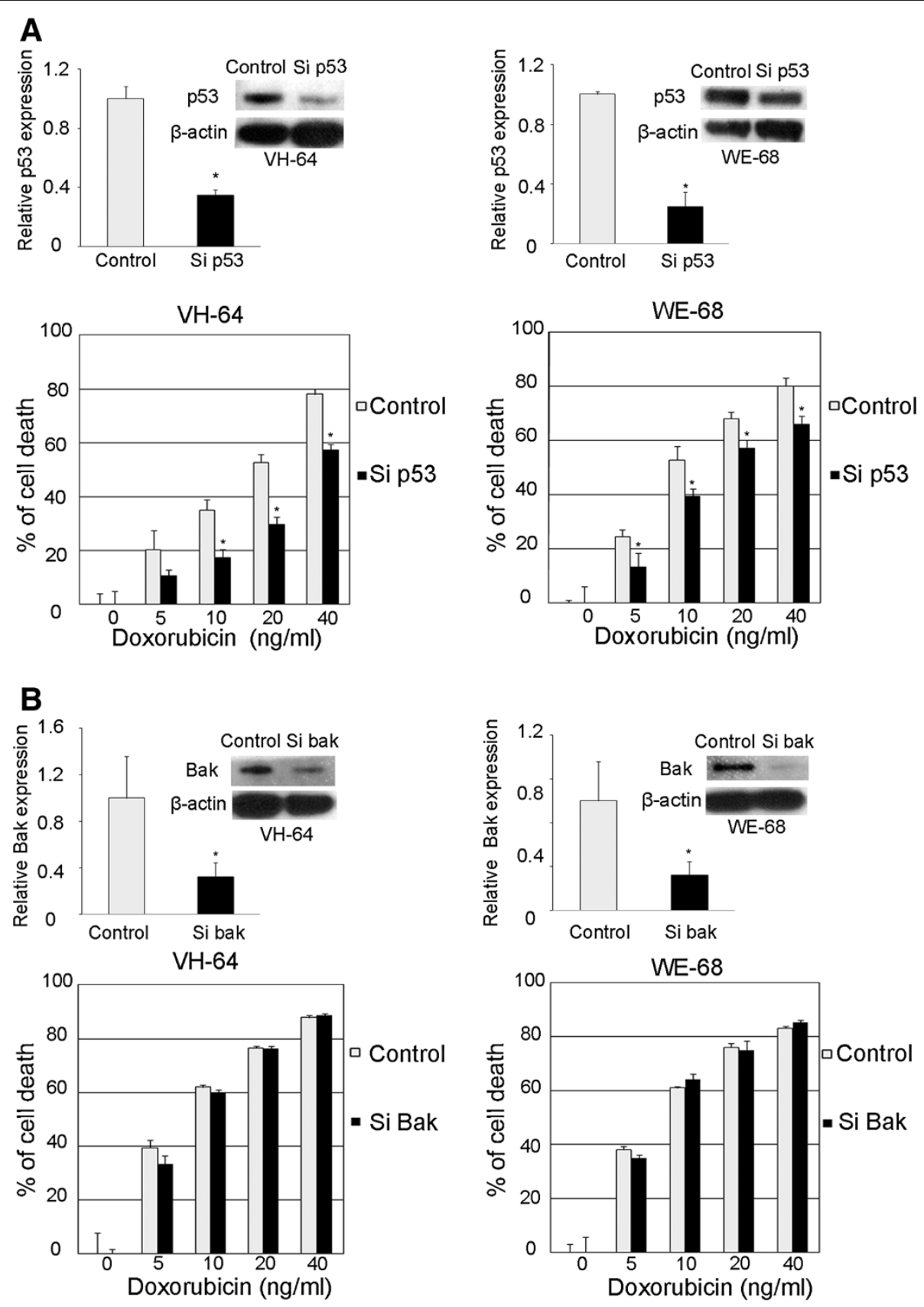

Figure 4 Changes in Dox-induced cytotoxicity after p53 and Bak knockdown in EWS cells. The VH-64 or WE-68 parental cell lines were transfected with $20 \mathrm{nM}$ of siRNA against p53 (A) or Bak (B). After $48 \mathrm{~h}$ incubation, the cells were collected, and qRT-PCR and an immunoblot analysis were performed to confirm the effects of the siRNA. The cells were seeded at $2 \times 10^{3}$ cells/well in 96 well plates and treated with various concentrations of doxorubicin for $48 \mathrm{~h}$. The cell viability was determined by the CellTiter-GloTM Luminescent Cell Viability Assay. The data represent the means of three separate experiments. The results are the means \pm SD. ${ }^{*}, P<0.05$.

resistant cells increased their sensitivity to vincristine and etoposide (Figure 6A, C). In contrast, when miR$125 \mathrm{~b}$ was overexpressed in the parental cells, reduced cytotoxicity was observed upon treatment with vincristine and etoposide (Figure 6B, C). Intriguingly, the Doxresistant cells showed almost the same sensitivity to mafosfamide as the parental cells. Knocking down miR$125 \mathrm{~b}$ enhanced the sensitivity of both parental and resistant cells to mafosfamide (Additional file 3: Figure S3). These observations suggest that miR-125b enhances the chemoresistance to multiple drugs used in the standard regimen for treating EWS. 

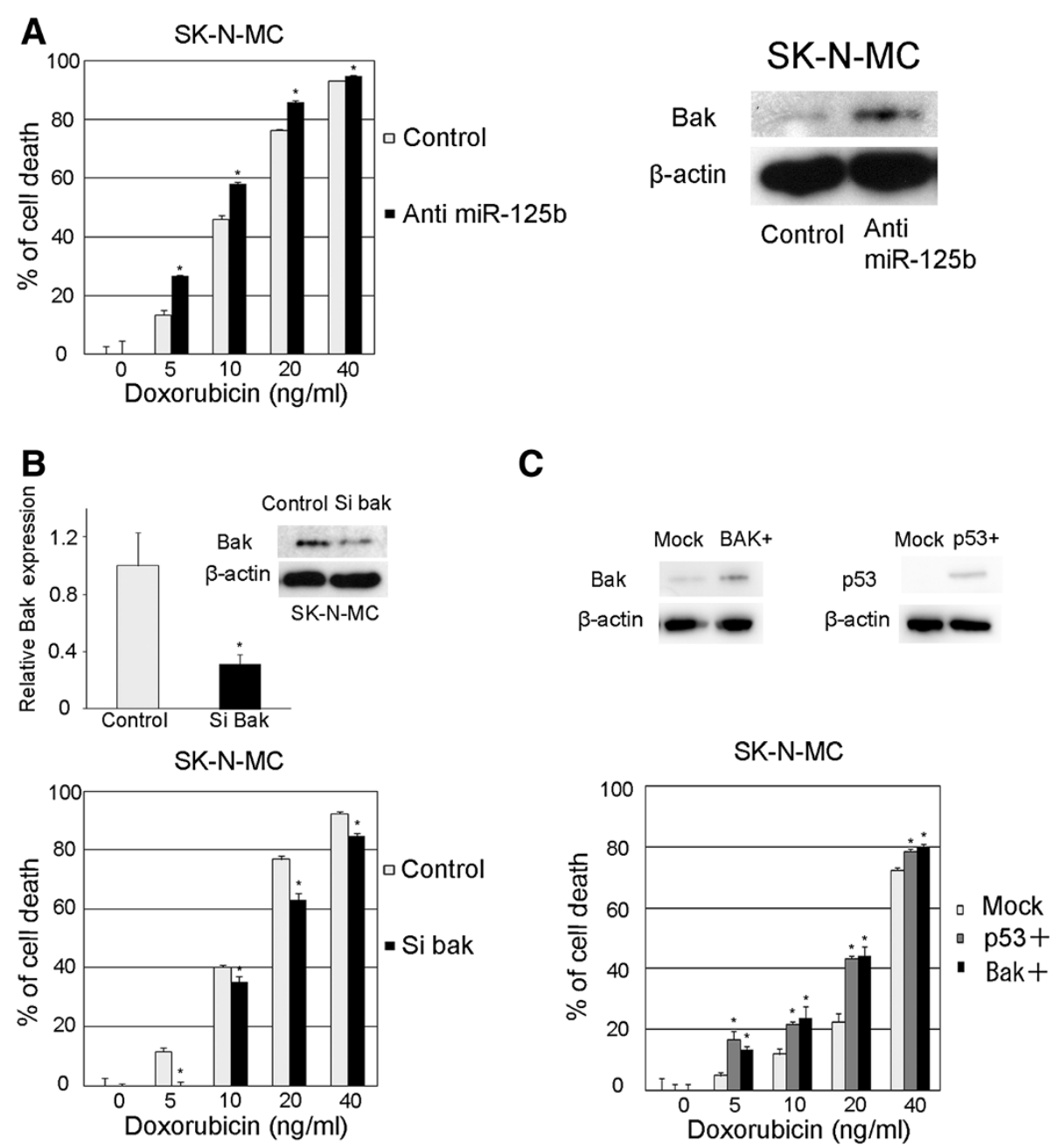

Figure 5 Changes in Dox-induced cytotoxicity after the downregulation of miR-125b and Bak in p53-truncated EWS cells. A) miR-125b was stably knocked down in SK-N-MC cells which express a truncated mutant of p53. The cells were seeded at $2 \times 10^{3}$ cells/well in 96 well plates and cultured for $12 \mathrm{~h}$, then were treated with various concentrations of doxorubicin for an additional $48 \mathrm{~h}$. (Left) The cell viability was determined by the CellTiter-GloTM Luminescent Cell Viability Assay. The data represent the means of three separate experiments. The results are the means \pm SD. * $\mathrm{P}<0.05$. (Right) The whole cell lysates were subjected to an immunoblot analysis using antibodies against Bak and $\beta$-actin. B) SK-N-MC cells were transfected with $20 \mathrm{nM}$ of siRNA against Bak. (Upper) After $48 \mathrm{~h}$ incubation, the cells were collected, and qRT-PCR and an immunoblot analysis were performed to confirm the effect of the siRNA. (Lower) Cells were seeded at $2 \times 10^{3}$ cells/well in 96 well plates, and were treated with various concentrations of doxorubicin for $48 \mathrm{~h}$. The cell viability was determined by the CellTiter-GloTM Luminescent Cell Viability Assay. The data represent the means of three separate experiments. The results are the means \pm SD. ${ }^{*}, \mathrm{P}<0.05$. C) p53, Bak or mock construct was introduced into SK-N-MC cells using a lentivirus. After $96 \mathrm{~h}$ incubation, the cells were seeded at $2 \times 10^{3}$ cells/well in 96 well plates. Twelve hours later, the cells were treated with various concentrations of doxorubicin for an additional $48 \mathrm{~h}$. The cell viability was detected by the CellTiter-GloTM Luminescent Cell Viability Assay. The data represent the means of three separate experiments. The results are the means \pm SD. ${ }^{*}, P<0.05$. Immunoblot analyses were performed to confirm the effects of the lentivirus induction.

\section{Discussion}

One major mechanism of drug resistance in cancer cells is the evasion of apoptosis [7,29]. Recent findings have revealed that miRNAs can modulate drug resistance by impairing the apoptotic pathway in various cancers $[19,24,30,31]$. In this study, we observed the upregulation of miR-125b in Dox-resistant EWS cells. When miR-125b was knocked down in EWS cells, both the Dox-resistant cells and the Dox-sensitive parental cells showed enhanced chemosensitivity to doxorubicin, and this was associated with the upregulation of the pro-apoptotic molecules, p53 and Bak. Conversely, overexpressing miR-125b in EWS cells resulted in enhanced drug resistance. We have previously reported the involvement of $\mathrm{ABC}$ transporters during the acquisition of multidrug resistance in EWS cells $[15,16]$. However, the drug resistance in those cells was not fully reversed in the presence of efflux pump inhibitors, so it was concluded 

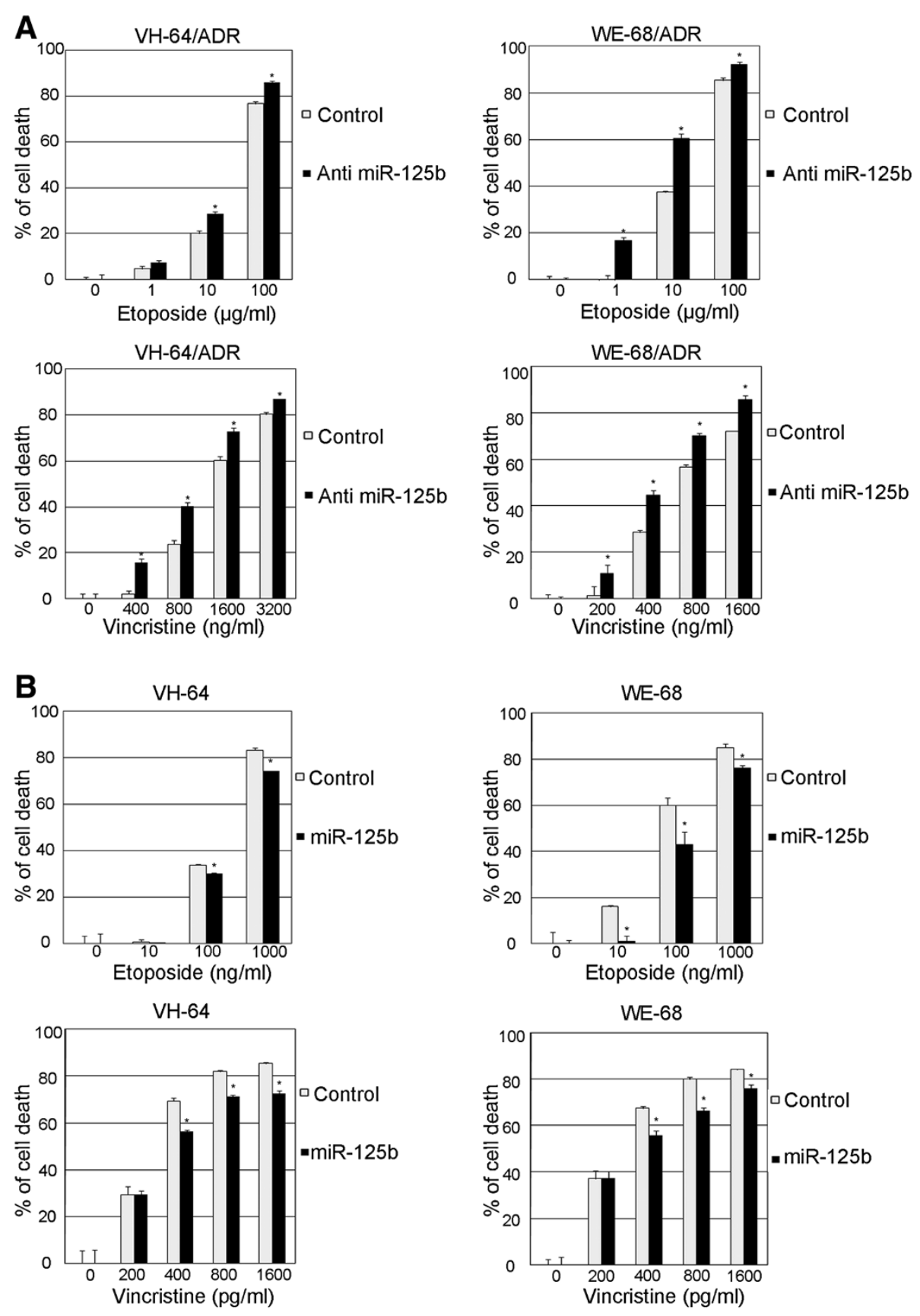

\begin{tabular}{|c|c|c|c|}
\hline \multicolumn{2}{|c|}{ Clones } & \multirow{2}{*}{$\begin{array}{c}\text { Etoposide }(\mu \mathrm{g} / \mathrm{ml}) \\
33.7 \\
23.5 \\
\end{array}$} & \multirow{2}{*}{$\begin{array}{c}\text { IC50 Vincristine }(\mathrm{ng} / \mathrm{ml}) \\
1310 \\
980\end{array}$} \\
\hline $\mathrm{VH}-64 / \mathrm{ADR}$ & $\begin{array}{l}\text { control } \\
125 \mathrm{~b}-\end{array}$ & & \\
\hline WE-64/ADR & $\begin{array}{l}\text { control } \\
125 \mathrm{~b}-\end{array}$ & $\begin{array}{l}18.3 \\
5.7\end{array}$ & $\begin{array}{l}678 \\
463 \\
\end{array}$ \\
\hline VH-64 & $\begin{array}{l}\text { control } \\
125 \mathrm{~b}+\end{array}$ & $\begin{array}{l}0.21 \\
0.28\end{array}$ & $\begin{array}{l}0.29 \\
0.34\end{array}$ \\
\hline WE-68 & $\begin{array}{l}\text { control } \\
125 b+\end{array}$ & $\begin{array}{l}0.06 \\
0.16\end{array}$ & $\begin{array}{l}0.27 \\
0.32\end{array}$ \\
\hline
\end{tabular}

Figure 6 (See legend on next page.) 
(See figure on previous page.)

Figure 6 The effects of miR-125b on the resistance of EWS cells to etoposide and vincristine. A) miR-125b was stably knocked down in Dox-resistant EWS cells. The cells were seeded at $2 \times 10^{3}$ cells/well in 96 well plates, cultured for $12 \mathrm{~h}$, and then treated with various concentrations of vincristine or etoposide for an additional $48 \mathrm{~h}$. The cell viability was determined by the CellTiter-GloTM Luminescent Cell Viability Assay The data represent the means of three separate experiments. The results are the means \pm SD. ${ }^{*}, \mathrm{P}<0.05$. B) Cells were seeded at $2 \times 10^{3}$ cells/well in 96 well plates $36 \mathrm{~h}$ after transfection with $100 \mathrm{nM}$ control or has-miR-125b miRNA Precursor. The cells were treated with various concentrations of vincristine or etoposide for an additional $48 \mathrm{~h}$. The cell viability was determined by the CellTiter-GloTM Luminescent Cell Viability Assay. The data represent the means of three separate experiments. The results are the means \pm SD. ${ }^{*}, \mathrm{P}<0.05$. C) The drug sensitivity of the EWS clones to various anticancer agents. IC50 showed drug concentrations that inhibited cell survival by $50 \%$.

that additional mechanisms of resistance were also likely to be involved. Our present observations clearly revealed the involvement of miR-125b during the acquisition of multidrug resistance in EWS cells.

It is known that miR-125b is a vertebrate homologue of the C. elegans microRNA lin-4, which regulates the reiterations of stem cells in C. elegans [32]. Similar to lin-4, miR-125b has been shown to regulate the homeostasis of mammalian neural and hematopoietic stem cells $[33,34]$. Several targets of miR-125b have been identified, including ETS [35], ERBB [36], p53 [37], Bak [23,24], and Lin28 [34], thus suggesting the involvement of miR$125 \mathrm{~b}$ and its targets in proliferation and apoptosis.

Recent reports suggest that miR-125b functions as a tumor suppressor in some types of tumors, such as breast cancer [35,38], thyroid cancer [39], and hepatocellular carcinoma [40]. In contrast, miR-125b was shown to function as an oncogene in B-cell leukemia [41], endometrial carcinoma [42], and colorectal cancer [43]. Shi et al. reported that the downregulation of miR-125b induced growth inhibition of prostate cancer cells, whereas the overexpression of miR-125b enhanced cell growth [23]. Our findings revealed that miR-125b acts as an oncogene in EWS cells by targeting p53 and Bak.

The tumor suppressor p53, recognized as the "guardian of the genome", regulates many downstream genes and plays a pivotal role in regulating the cell cycle and cell death. Recent studies have revealed that several miRNAs, including miR-125b, directly target p53 [22]. The loss of miR-125b increases widespread p53-dependent apoptosis, leading to severe defects in zebrafish embryos [37]. Direct suppression of $\mathrm{p} 53$ by miR-125b affects the camptothecininduced apoptosis in various cancer cell types [25], and was assumed to be associated with a poor prognosis of colorectal cancer [43]. The results of our current study are consistent with these previous reports that miR-125b acts as an oncogene by suppressing p53-dependent apoptosis (Figure 3). Intriguingly, an anti-apoptotic role of miR-125b, mediated through the suppression of multiple proapoptotic regulators in the p53 network, is conserved in vertebrates [37], suggesting the importance of miR-125b in regulating $\mathrm{p} 53$.

Although the function of p53 is reported to be disrupted in a wide variety of tumors, p53 mutations are uncommon in EWS. The majority of EWS tumors express wild-type p53 [44]. Instead of genetic alterations, the inactivation of p53 during the development and progression of EWS has been explained by the interaction between p53 and the EWS/FLI1 fusion gene [45]. We have reported that EWS/FLl1 interacts with p53, impairs its transcriptional activity, and inhibits the expression of its downstream target genes [46]. In addition to these post-translational modifications by EWS/FLI1, miR-125b may regulate the expression of p53 post-transcriptionally by interacting with its 3'UTR in EWS [22,37].

Bak is a pro-apoptotic mitochondrial membrane protein, usually inactivated by the formation of complexes with the anti-apoptotic Bcl2 family protein, Mcl1. Bak has been reported to be a target of miR-125b, which has been implicated in the androgen-independent growth of prostate cancer cells [23], and also in paclitaxel-induced apoptosis in breast cancer cells [47]. In this study, we showed that Bak is also involved in miR-125b-mediated Dox-resistance in EWS cells. The downregulation of Bak reduced chemosensitivity only in the p53-truncated SK-N-MC cells (Figure 5B), indicating the importance of wild-type p53 during Dox-induced cytotoxicity in EWS. Of note, p53 was shown to bind to Bak following genotoxic stress, and to induce its oligomerization, leading to cytochrome c release [48]. Although we have not examined the direct interaction of p53 with Bak in EWS cells, these observations indicate that, in the absence of p53, the miR-125bBak axis plays a role in the chemosensitivity in EWS cells.

The role of microRNAs in EWS remains largely unclear. Very recently, Italian investigators revealed the involvement of miR-34a in the chemoresistance of EWS [20]. They screened miRNAs by discriminating EWS patients with different clinical outcomes and successfully identified miR-34a as a regulator of chemosensitivity and a possible prognostic marker. On the other hand, we screened Dox-resistant EWS cells and found miR-125b to be upregulated in the resistant cells. Upregulation of miR-125b was also confirmed in the EWS tumors having survived chemotherapy regimens that included doxorubicin. Although the screening methods are different in these studies, both studies clearly demonstrate the involvement of miRNAs in the development of chemoresistance in EWS. 
Upregulation of miR-125b has been reported in various tumors, including B-cell leukemia, endometrial carcinoma and colorectal cancer [41-43]. In regard to Dox-resistant cell lines, upregulation of miR-125b was observed in the malignant peripheral nerve sheath tumor cells, FUSFT9817, but not in the osteosarcoma cell line MNNG (Additional file 4: Figure S4). It appears that the upregulation of miR-125b in tumor cells occurs in a cell typedependent manner. Thus far, the underlying mechanism responsible for this upregulation remains unclear. The contribution of NF-kB p65 binding sites as well as CpGrich regions upstream of miR-125b-1 in the regulation of miR-125b has been postulated [35,47]. We observed no differences in the copy numbers of miR-125b genes between the parental and Dox-resistant EWS cells (Additional file 5: Figure S5), suggesting epigenetic regulation of the miR-125b expression in Dox-resistant EWS cells. Further studies are required to elucidate the mechanisms regulating the miR-125b expression.

Since the introduction of the VDC-IE regimen, the 5 -year survival rates for patients with localized disease have ranged from 60 to $70 \%[1,28]$. Nevertheless, EWS still has a low survival rate because of the frequent development of recurrence and/or metastatic lesions, which are usually associated with the acquisition of multidrug resistance [28]. We have observed that miR-125b significantly affected the chemosensitivity of EWS to doxorubicin, vincristine, etoposide (Figure 6), and mafosfamide (Additional file 3: Figure S3). As shown in Figure 1C, miR-125b was significantly upregulated in EWS tumors after VDC-IE or VAIA treatment. Upregulation of miR-125b upon chemotherapy have been reported in colorectal cancer [49], and breast cancer [47]. These observations suggest that the acquisition of drug resistance may be regulated, at least partly, via the miR-125b-p53/Bak pathway.

\section{Conclusions}

In summary, miR-125b was commonly upregulated in Dox-resistant EWS cells as well as in EWS tumors having survived chemotherapy. miR-125b led to the development of chemoresistance by suppressing the expression of p53 and Bak, and repression of miR-125b sensitized EWS cells to apoptosis induced by treatment with various cytotoxic drugs. Elucidating the involvement of miRNAs in the development of chemoresistance should be required to further improve the clinical prognosis for EWS.

\section{Methods}

\section{Reagents}

Doxorubicin was obtained from Kyowa Hakko (Tokyo, Japan). Etoposide was obtained from Calbiochem (San Diego, CA). Vincristine and mafosfamide were obtained from Wako (Osaka, Japan).

\section{Cells and cell culture}

The human EWS cell lines, VH-64 and WE-68 (with wild type p53), and SK-N-MC (with a p53 truncation), and RD-ES, SK-ES, and TC-71 (with mutant type p53) were cultured in RPMI-1640 (Invitrogen, Carlsbad, CA) containing 10\% fetal bovine serum (HyClone Laboratories, Inc., Logan, UT). The Dox-resistant EWS clones VH-64/ADR and WE-68/ADR were established and characterized in our laboratory [16], and cultured in RPMI-1640 containing 10\% fetal bovine serum with $100 \mathrm{ng} / \mathrm{ml}$ of doxorubicin. The cells were incubated at $37^{\circ} \mathrm{C}$ in a humidified atmosphere containing $5 \% \mathrm{CO}_{2}$.

\section{miRNA extraction from clinical samples}

The study population consisted of 11 serial cases retrieved from the archives of the Department of Anatomic Pathology, Pathological Sciences, Graduate School of Medical Science, Kyushu University, Japan. The tissue specimens were collected during primary tumor open biopsy at diagnosis between 2002 and 2008. In each case, a diagnosis of EWS was made based on the histological features of the specimen. From these 11 cases, six cases were excluded because of a lack of availability of adequate tissue. The remaining five cases were treated with systemic VDC-IE or VAIA regimen [1], and then the tumors were resected.

The expression profiles of miRNAs were reported to be in good correlation between fresh frozen and formalinfixed, paraffin-embedded (FFPE) samples [50,51]. Therefore, all samples were prepared as FFPE sections. Thereafter, $4 \mu \mathrm{m}$ sections of FFPE tissues were deparaffinized with $\mathrm{xy}$ lene, washed in ethanol, and digested with proteinase $\mathrm{K}$. Total RNA was extracted using a miRNeasy FFPE kit (Qiagen, Valencia, CA). Ten nanograms of total RNA from each sample were used for cDNA synthesis. The Institutional Review Board at Kyushu University approved the use of human specimens for this study (Reference number 21-124).

\section{Quantitative real-time PCR (qRT-PCR)}

For the miRNA expression analysis, total RNA was purified from harvested cells using a miRNeasy Mini Kit (Qiagen). The total RNA was used in a reverse transcription reaction with a MiScript Reverse Transcription Kit (Qiagen). Real-time PCR was carried out using a LightCycler 1.5 (Roche Diagnotics, Indianapolis, IN) with miRNA-specific primers (Qiagen) according to the manufacturer's instructions (miScript SYBR Green PCR kit, Qiagen). RNU6B was used as an internal control. The RT reactions were performed using the following conditions: an initial denaturation step at $95^{\circ} \mathrm{C}$ for $15 \mathrm{~min}$, followed by 40 cycles of denaturation at $94^{\circ} \mathrm{C}$ for $15 \mathrm{~s}$, annealing at $55^{\circ} \mathrm{C}$ for $30 \mathrm{~s}$, and extension at $70^{\circ} \mathrm{C}$ for $30 \mathrm{~s}$. 
For the mRNA expression analysis [52], total RNA was extracted using an RNeasy kit (Qiagen). The total RNA was used in a reverse transcription reaction with SuperScriptII reverse transcriptase (Invitrogen). Realtime PCR was carried out using a LightCycler 1.5 with mRNA-specific primers according to the manufacturer's instructions (Perfect Real Time, Takara Bio, Shiga, Japan). Glyceraldehyde 3-phosphate dehydrogenase (GAPDH) was used as an internal control. The RT reactions were performed under the following conditions: an initial denaturation step at $95^{\circ} \mathrm{C}$ for $5 \mathrm{~s}$, followed by 40 cycles of denaturation at $95^{\circ} \mathrm{C}$ for $10 \mathrm{~s}$, and annealing at $60^{\circ} \mathrm{C}$ for 30 s. The following primers were used: Bak (forward: 5' -CTTCGTGGTCGACTTCATGCT-3' and reverse: 5' GGACCATTGCCCAAGTTCAG-3'; product size 93 bp), p53 (forward: 5' -ACTAAGCGAGCACTGCCCAAC-3' and reverse: 5' -CCTCATTCAGCTCTCGGAACATC-3'; product size $130 \mathrm{bp}$ ), and GAPDH (forward: 5' -GAAGGT GAAGGTCGGAGTC-3' and reverse: 5'-GAAGATGGT GATGGGATTTC-3'; product size 226 bp).

The expression levels of miRNAs, mRNAs, and DNAs were calculated using the LightCycler version 3.5 software program (Roche Diagnotics). A negative control was also prepared using distilled water instead of a DNA template. The assay was performed in triplicate and was repeated in at least three separate experiments.

\section{siRNA and miRNA experiments}

The cells were seeded at $1.5 \times 10^{5}$ cells per well in 6 well plates. After $24 \mathrm{~h}$ in culture, the cells were transfected with p53 siRNA (Ambion ID 605), Bak siRNA (Ambion ID 1880), has-miR-125b miRNA Precursor (Ambion ID PM10148) or Silencer Negative Control \#1 siRNA (Ambion, Austin, TX) using Lipofectamine2000 (Invitrogen) according to the manufacturer's protocols. The introduction of the miRNAs was confirmed by qRT-PCR (Additional file 6: Figure S6), and the introduction of the siRNAs was confirmed by qRT-PCR and immunoblotting. Thirty-six hours after transfection, a chemosensitivity assay was performed as described below.

\section{Chemosensitivity assay}

For the chemosensitivity assay, cells were seeded at $2 \times 10^{3}$ cells per well in 96 well plates. After $12 \mathrm{~h}$ incubation, various concentrations of drugs were added to the medium. After another incubation for $48 \mathrm{~h}$, the number of viable cells in each well was measured using the CellTiterGloTM Luminescent Cell Viability kit (Promega, Madison, WI), according to the manufacturer's protocol. Before the use of Dox-resistant clones in this assay, they were cultured in medium without doxorubicin for 10 days. The chemosensitivity assay was carried out in triplicate and was repeated at least three times in separate experiments.

\section{Profiling microRNA expression by Luminex}

The total RNA from VH-64 and VH-64/ADR cells was extracted using a Vantage ${ }^{\mathrm{TM}}$ Total RNA Purification Kit (Origene, Rockville, MD). A $2 \mu \mathrm{g}$ aliquot of total RNA was labeled with biotin by the Vantage ${ }^{\mathrm{TM}}$ microRNA Labeling Kit (Origene) as described in the manufacturer's protocol. The labeled total RNA was hybridized to Bead Mix (Vantage $^{\mathrm{TM}}$ microRNA Multiplex Detection Kit Oncology Detection Panel, Origene) at $60^{\circ} \mathrm{C}$ by using a thermocycler for one hour. The hybridized reactions were transferred to 96 well filter plates. After several washing steps, the filter plate was read using a Luminex100 instrument (Luminex Corp., Austin, TX) [53].

\section{Lentiviral vector construction and production}

miRNA expression vectors (miRZip Anti-miR-125b microRNA Construct, miRZip Anti-miR-93 microRNA Construct and Scramble Hairpin Control Anti-microRNA Construct, System Biosciences, Mountain View, CA) and the Lentivirus Package plasmid mix (System Biosciences) were co-transfected into 293TN (System Biosciences) cells with Lipofectamine2000 (Invitrogen) according to the manufacturer's protocol. The culture supernatants were collected $48 \mathrm{~h}$ post-transfection. The supernatant was concentrated by PEG-it Virus Precipitation Solution (System Biosciences), and the concentrated supernatant was used to infect target cells.

To create p53 and Bak lentiviral vectors, we inserted p53 and Bak cDNA into pCDH-EF1-MCS-IRES-Puro (System Biosciences). These vectors were co-transfected with Package plasmid mix into 293TN, and the concentrated supernatant was used.

\section{Lentiviral infection}

Cells were plated at a density of $0.5 \times 10^{5}$ cells per well in 24 well plates with RPMI (with serum, but without antibodies). After $24 \mathrm{~h}$ incubation, the cells were transfected with lentivirus particles using the TransDux Virus Transduction Reagent (System Biosciences). Two days after transfection, puromycin was added to the medium to establish cells with stable miR-125b knock down. Almost all cells were confirmed to be infected by counting GFP-positive cells 2 weeks after the transfection (Additional file 7: Figure S7).

\section{Western blot analysis}

The cells were washed twice with ice-cold PBS, scraped, collected in a microcentrifuge tube, and then centrifuged. The cells were lysed using CelLytic (Sigma Aldrich, St. Louis, MO) with a protease inhibitor cocktail (Complete Mini, EDTA-free; Roche Diagnotics). After incubating the cells for $10 \mathrm{~min}$ on ice, the cellular debris was pelleted by centrifuging for $15 \mathrm{~min}$ at $12000 \times \mathrm{g}$ at $4^{\circ} \mathrm{C}$. The protein quantity in the lysate was determined using a Bradford 
protein assay (Bio-Rad, Richmond, CA). The samples were boiled for $5 \mathrm{~min}$, and each of the samples was separated on a $4-12 \%$ gradient pre-cast MOPS polyacrylamide gel (Novex, San Diego, CA) and transferred onto a nitrocellulose membrane. The filter was blocked with TBS containing $5 \%$ non-fat dry milk and $0.1 \%$ Tween 20 for $1 \mathrm{~h}$ at room temperature. The filter was then incubated overnight with the appropriate primary antibodies at $4{ }^{\circ} \mathrm{C}$. The following primary antibodies were used: P-gp (Alexis Biochemicals, San Diego, CA), p53 and $\beta$-actin (Santa Cruz Biotechnology, Santa Cruz, CA), Bak (Abcam, Cambridge, UK), caspase 3 (BD Biosciences, San Jose, CA), and cleaved caspase 3 (Cell Signaling, Beverly, MA). After washing the filter, a horseradish peroxidaseconjugated secondary antibody (Santa Cruz Biotechnology) was added, and the filter was incubated at room temperature for $1 \mathrm{~h}$. After a final wash with TBST, the immunoreactivity of the blots was detected using an enhanced chemiluminescence (ECL) detection system (Amersham, Buckinghamshire, UK).

\section{Active caspase 3 ELISA}

Cells were seeded at $5 \times 10^{5}$ cells per well in 12 well plates and incubated with $100 \mathrm{ng} / \mathrm{ml}$ doxorubicin. After $24 \mathrm{~h}$ incubation, the cells were harvested. The concentrations of active caspase 3 were measured according to the manufactures instructions (R\&D Systems, Minneapolis, MN).

\section{Statistical analysis}

Statistical comparisons were performed using Student's $t$-test. The minimal level of significance was considered to be $\mathrm{P}=0.05$.

\section{Consent}

Written informed consent was obtained from the patient for publication of this report and any accompanying images.

\section{Additional files}

Additional file 1: Figure S1. The effects of miR-125b on the Doxinduced cytotoxicity in EWS cells. miR-125b was stably knocked down in EWS cells (RD-ES, SK-ES, and TC-71). The cells were seeded at $2 \times 10^{3}$ cells/well in 96 well plates, cultured for $12 \mathrm{~h}$, and then treated with various concentrations of doxorubicin for an additional $48 \mathrm{~h}$. The cell viability was determined by the CellTiter-GloTM Luminescent Cell Viability Assay The data represent the means of three separate experiments. The results are the means $\pm \mathrm{SD}$. ${ }^{*}, \mathrm{P}<0.05$.

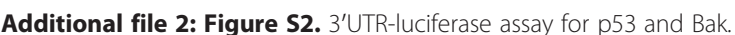
Reporter luciferase vectors containing the $3^{\prime} U T R$ of $p 53$ and Bak were purchased from Ambion, and random control vectors were purchased from Switchgear genomics (Menlo Park, CA). Cells were seeded at a density of $2 \times 10^{5}$ cells per well in 12 well plates. The cells were cotransfected with luciferase reporters and has-miR-125b miRNA Precursor or Silencer Negative Control \#1 siRNA. After 36 h incubation, the cells were collected. The luciferase activity was measured using a dual luciferase reporter assay (Promega). The PRL-TK vector was used as an internal control. The results are expressed as the relative luciferase activity (firefly Luc/Renilla Luc). The results are the means $\pm S D$. ${ }^{*}, P<0.05$.

Additional file 3: Figure S3. The effects of miR-125b on the sensitivity of EWS cells to mafosfamide. An antisense or control construct was introduced into the parental cells (A), and the Dox-resistant cells (B) using a lentivirus. The cells were cultured with puromycin for 2 weeks to ensure a stable knockdown, and then were seeded at $2 \times 10^{3}$ cells/well in 96 well plates. Twelve hours later, the cells were treated with various concentrations of mafosfamide for an additional $48 \mathrm{~h}$. The cell viability was detected by the CellTiter-GloTM Luminescent Cell Viability Assay. The data represent the means of three separate experiments. The results are the means $\pm S D$. ${ }^{*}, P<0.05$.

Additional file 4: Figure S4. The miRNA expression levels in the Doxresistant tumor cells. qRT-PCR was performed to investigate the expression of miR-125b in Dox-resistant cell lines. RNU6B was used as an internal control. The data represent the means of three separate experiments. The results are the means \pm SD. ${ }^{*}, P<0.05$.

Additional file 5: Figure S5. The copy number analysis of miR-125b in VH-64 and VH-64/ADR. Quantitative-PCR was performed to examine the copy numbers of miR-125b in VH-64 and VH-64/ADR. DNA was extracted using DNeasy (Qiagen), and real-time PCR was carried out using a LightCycler 1.5 with specific primers according to the manufacturer's instructions (Perfect Real Time, Takara Bio). The GAPDH and TNSALP (Tissue non-specific alkaline phosphatase) genes were used as control 1 and control 2, respectively. The PCR reactions were performed under the following conditions: an initial denaturation step at $95^{\circ} \mathrm{C}$ for $5 \mathrm{~s}$, followed by 40 cycles of denaturation at $95^{\circ} \mathrm{C}$ for $10 \mathrm{~s}$ and annealing at $60^{\circ} \mathrm{C}$ for $30 \mathrm{~s}$. The following primers were used: miR-125b-1 (forward: 5'- CTGGT CACCTGATCCCATCT-; $3^{\prime}$ and reverse: 5'-ATTGTTGCGCTCCTCTCAGT-3'; product size $217 \mathrm{bp}$ ), miR-125b-2 (forward: 5'-CCGCATCAAACCAGACT TाT-3' and reverse: 5'-GGATGGGTCATGGTGAAAAC-3'; product size 228 bp), control 1 (forward: 5'-CAACGAATTGGCTACAGCA-3' and reverse: 5'- AGGGGTCTACATGGCAACTG-3'; product size 195 bp), and control 2 (forward: 5'- AGGAGCACGAGAGACTGAGG-3' and reverse: 5'- CTGGCT GCTGTCATGTTCAG-3'; product size 232 bp). The data represent the means of three separate experiments.

Additional file 6: Figure S6. The induction of miR-125b in parental EWS cells. The VH-64 or WE-68 parental cell lines were transfected with100 nM control or has-miR-125b miRNA Precursor. After $48 \mathrm{~h}$ incubation, the cells were collected, and QRT-PCR was performed to confirm the expression of miR-125b.

Additional file 7: Figure S7. The knockdown of miR-125b using the lentivirus. Cells were infected with the miRZip lentivirus construct, then the induction of the anti-miR-125b was confirmed by GFP-positivity in almost all of the cells.

\section{Abbreviations}

miRNA: microRNA; EWS: Ewing sarcoma/primitive neuroectodermal tumor; Dox: Doxorubicin; P-gp: P-glycoprotein; GAPDH: Glyceraldehyde 3-phosphate dehydrogenase; FFPE: Formalin-fixed, paraffin-embedded.

\section{Competing interests}

The authors declare that they have no competing interests.

\section{Authors' contributions}

$\mathrm{KI}, \mathrm{JF}, \mathrm{YI}$ designed research and analyzed data. YM, YO, YT, TF, YF-O, MH, AN, and SK carried out molecular biology studies. KI and JF wrote the paper. All authors read and approved the final manuscript.

\section{Acknowledgements}

This work was supported by a Grant-in-Aid for Scientific Research (19390397) from the Japan Society for the Promotion of Science (Y. Iwamoto), and a Grant-in-Aid for Clinical Research Evidence-Based Medicine and Cancer Research from the Ministry of Health, Labour and Welfare of Japan (Y. Iwamoto).

\section{Author details}

'Department of Orthopaedic Surgery, Graduate School of Medical Sciences, Kyushu University, Maidashi3-1-1, Fukuoka 812-8582, Japan. ${ }^{2}$ Department of 
Anatomical Pathology, Graduate School of Medical Sciences, Kyushu University, Maidashi3-1-1, Fukuoka 812-8582, Japan.

Received: 10 October 2012 Accepted: 28 February 2013 Published: 4 March 2013

\section{References}

1. Iwamoto Y: Diagnosis and treatment of Ewing's sarcoma. Jpn J Clin Oncol 2007, 37:79-89.

2. Grier HE, Krailo MD, Tarbell NJ, Link MP, Fryer CJ, Pritchard DJ, Gebhardt MC, Dickman PS, Perlman EJ, Meyers PA, Donaldson SS, Moore S, Rausen AR, Vietti TJ, Miser JS: Addition of ifosfamide and etoposide to standard chemotherapy for Ewing's sarcoma and primitive neuroectodermal tumor of bone. N Engl J Med 2003, 348:694-701.

3. Meyers PA, Krailo MD, Ladanyi M, Chan KW, Sailer SL, Dickman PS, Baker DL, Davis JH, Gerbing RB, Grovas A, Herzog CE, Lindsley KL, Liu-Mares W, Nachman JB, Sieger L, Wadman J, Gorlick RG: High-dose melphalan, etoposide, total-body irradiation, and autologous stem-cell reconstitution as consolidation therapy for high-risk Ewing's sarcoma does not improve prognosis. J Clin Oncol 2001, 19:2812-2820.

4. Miser JS, Krailo MD, Tarbell NJ, Link MP, Fryer CJ, Pritchard DJ, Gebhardt MC, Dickman PS, Perlman EJ, Meyers PA, Donaldson SS, Moore S, Rausen AR, Vietti TJ, Grier HE: Treatment of metastatic Ewing's sarcoma or primitive neuroectodermal tumor of bone: evaluation of combination ifosfamide and etoposide-a Children's cancer group and pediatric oncology group study. J Clin Oncol 2004, 22:2873-2876.

5. Rodriguez-Galindo C, Billups CA, Kun LE, Rao BN, Pratt CB, Merchant TE, Santana VM, Pappo AS: Survival after recurrence of Ewing tumors: the St Jude Children's Research Hospital experience, 1979-1999. Cancer 2002, 94:561-569.

6. Shankar AG, Ashley S, Craft AW, Pinkerton CR: Outcome after relapse in an unselected cohort of children and adolescents with Ewing sarcoma. Med Pediatr Oncol 2003, 40:141-147.

7. Fodale V, Pierobon M, Liotta L, Petricoin E: Mechanism of cell adaptation: when and how do cancer cells develop chemoresistance? Cancer J 2011 , 17:89-95.

8. Scotlandi K, Avnet S, Benini S, Manara MC, Serra M, Cerisano V, Perdichizzi S, Lollini PL, De Giovanni C, Landuzzi L, Picci P: Expression of an IGF-I receptor dominant negative mutant induces apoptosis, inhibits tumorigenesis and enhances chemosensitivity in Ewing's sarcoma cells. Int J Cancer 2002, 101:11-16.

9. Scotlandi K, Manara MC, Nicoletti G, Lollini PL, Lukas S, Benini S, Croci S, Perdichizzi S, Zambelli D, Serra M, Garcia-Echeverria C, Hofmann F, Picci P: Antitumor activity of the insulin-like growth factor-I receptor kinase inhibitor NVP-AEW541 in musculoskeletal tumors. Cancer Res 2005, 65:3868-3876.

10. Gonzalez I, Andreu EJ, Panizo A, Inoges S, Fontalba A, Fernandez-Luna JL, Gaboli M, Sierrasesumaga L, Martin-Algarra S, Pardo J, Prosper F, de Alava E: Imatinib inhibits proliferation of Ewing tumor cells mediated by the stem cell factor/KIT receptor pathway, and sensitizes cells to vincristine and doxorubicin-induced apoptosis. Clin Cancer Res 2004, 10:751-761.

11. Scotlandi K, Manara MC, Strammiello R, Landuzzi L, Benini S, Perdichizzi S, Serra M, Astolfi A, Nicoletti G, Lollini PL, Bertoni F, Nanni P, Picci P: C-kit receptor expression in Ewing's sarcoma: lack of prognostic value but therapeutic targeting opportunities in appropriate conditions. J Clin Oncol 2003, 21:1952-1960.

12. Scotlandi K, Baldini N, Cerisano V, Manara MC, Benini S, Serra M, Lollini PL, Nanni P, Nicoletti G, Bernard G, Bernard A, Picci P: CD99 engagement: an effective therapeutic strategy for Ewing tumors. Cancer Res 2000, 60:5134-5142.

13. Jiang $X$, Gwye $Y$, Russell D, Cao C, Douglas D, Hung L, Kovar H, Triche TJ, Lawlor ER: CD133 expression in chemo-resistant Ewing sarcoma cells. BMC Cancer 2010, 10:116

14. Ganjavi H, Gee M, Narendran A, Freedman MH, Malkin D: Adenovirusmediated p53 gene therapy in pediatric soft-tissue sarcoma cell lines: sensitization to cisplatin and doxorubicin. Cancer Gene Ther 2005, 12:397-406.

15. Nakamura T, Tanaka K, Matsunobu T, Okada T, Nakatani F, Sakimura R, Hanada M, Iwamoto $Y$ : The mechanism of cross-resistance to proteasome inhibitor bortezomib and overcoming resistance in Ewing's family tumor cells. Int J Oncol 2007, 31:803-811.
16. Okada T, Tanaka K, Nakatani F, Sakimura R, Matsunobu T, Li X, Hanada M, Nakamura T, Oda Y, Tsuneyoshi M, Iwamoto Y: Involvement of Pglycoprotein and MRP1 in resistance to cyclic tetrapeptide subfamily of histone deacetylase inhibitors in the drug-resistant osteosarcoma and Ewing's sarcoma cells. Int J Cancer 2006, 118:90-97.

17. Bartel DP: MicroRNAs: genomics, biogenesis, mechanism, and function. Cell 2004, 116:281-297.

18. Esquela-Kerscher A, Slack FJ: Oncomirs - microRNAs with a role in cancer. Nat Rev Cancer 2006, 6:259-269.

19. Ma J, Dong C, Ji C: MicroRNA and drug resistance. Cancer Gene Ther 2010, 17:523-531.

20. Nakatani F, Ferracin M, Manara MC, Ventura S, Del Monaco V, Ferrari S, Alberghini M, Grilli A, Knuutila S, Schaefer KL, Mattia G, Negrini M, Picci P, Serra M, Scotlandi K: miR-34a predicts survival of Ewing's sarcoma patients and directly influences cell chemosensitivity and malignancy. J Pathol 2011, 226:796-805.

21. Skladanowski A, Konopa J: Adriamycin and daunomycin induce programmed cell death (apoptosis) in tumour cells. Biochem Pharmacol 1993, 46:375-382.

22. Kumar M, Lu Z, Takwi AA, Chen W, Callander NS, Ramos KS, Young KH, Li Y: Negative regulation of the tumor suppressor p53 gene by microRNAs. Oncogene 2011, 30:843-853.

23. Shi XB, Xue L, Yang J, Ma AH, Zhao J, Xu M, Tepper CG, Evans CP, Kung HJ, deVere White RW: An androgen-regulated miRNA suppresses Bak1 expression and induces androgen-independent growth of prostate cancer cells. Proc Natl Acad Sci USA 2007, 104:19983-19988.

24. Shi $X B$, Xue L, Ma AH, Tepper CG, Kung HJ, White RW: miR-125b promotes growth of prostate cancer xenograft tumor through targeting proapoptotic genes. Prostate 2011, 71:538-549.

25. Zeng CW, Zhang XJ, Lin KY, Ye H, Feng SY, Zhang H, Chen YQ: Camptothecin Induces Apoptosis in Cancer Cells via miR-125b Mediated Mitochondrial Pathways. Mol Pharmacol 2012, 81:578-586.

26. Panaretakis T, Pokrovskaja K, Shoshan MC, Grander D: Activation of Bak, Bax, and BH3-only proteins in the apoptotic response to doxorubicin. J Biol Chem 2002, 277:44317-44326.

27. Biedler $J$, Helson L, Spengler BA: Morphology and growth, tumorigenicity, and cytogenetics of human neuroblastoma cells in continuous culture. Cancer Res 1973, 33:2643-2652.

28. Balamuth NJ, Womer RB: Ewing's sarcoma. Lancet Oncol 2010, 11:184-192.

29. Fulda S: Tumor resistance to apoptosis. Int J Cancer 2009, 124:511-515.

30. Xia L, Zhang D, Du R, Pan Y, Zhao L, Sun S, Hong L, Liu J, Fan D: miR-15b and miR-16 modulate multidrug resistance by targeting $B C L 2$ in human gastric cancer cells. Int J Cancer 2008, 123:372-379.

31. Zhu W, Shan X, Wang T, Shu Y, Liu P: miR-181b modulates multidrug resistance by targeting BCL2 in human cancer cell lines. Int J Cancer 2010, 127:2520-2529.

32. Chalfie M, Horvitz HR, Sulston JE: Mutations that lead to reiterations in the cell lineages of C. elegans. Cell 1981, 24:59-69.

33. Guo S, Lu J, Schlanger R, Zhang H, Wang JY, Fox MC, Purton LE, Fleming $\mathrm{HH}$, Cobb B, Merkenschlager M, Golub TR, Scadden DT: MicroRNA miR125a controls hematopoietic stem cell number. Proc Natl Acad Sci USA 2010, 107:14229-14234.

34. Rybak A, Fuchs H, Smirnova L, Brandt C, Pohl EE, Nitsch R, Wulczyn FG: A feedback loop comprising lin-28 and let-7 controls pre-let-7 maturation during neural stem-cell commitment. Nat Cell Biol 2008, 10:987-993.

35. Zhang Y, Yan LX, Wu QN, Du ZM, Chen J, Liao DZ, Huang MY, Hou JH, Wu QL, Zeng MS, Huang WL, Zeng YX, Shao JY: miR-125b is methylated and functions as a tumor suppressor by regulating the ETS1 proto-oncogene in human invasive breast cancer. Cancer Res 2011, 71:3552-3562.

36. Scott GK, Goga A, Bhaumik D, Berger CE, Sullivan CS, Benz CC: Coordinate suppression of ERBB2 and ERBB3 by enforced expression of micro-RNA miR-125a or miR-125b. J Biol Chem 2007, 282:1479-1486.

37. Le MT, Teh C, Shyh-Chang N, Xie H, Zhou B, Korzh V, Lodish HF, Lim B: MicroRNA$125 \mathrm{~b}$ is a novel negative regulator of p53. Genes Dev 2009, 23:862-876.

38. Iorio MV, Ferracin M, Liu CG, Veronese A, Spizzo R, Sabbioni S, Magri E, Pedriali M, Fabbri M, Campiglio M, Menard S, Palazzo JP, Rosenberg A, Musiani P, Volinia S, Nenci I, Calin GA, Querzoli P, Negrini M, Croce CM: MicroRNA gene expression deregulation in human breast cancer. Cancer Res 2005, 65:7065-7070.

39. Visone R, Pallante $P$, Vecchione A, Cirombella R, Ferracin M, Ferraro A, Volinia S, Coluzzi S, Leone V, Borbone E, Liu CG, Petrocca F, Troncone G, 

carcinomas. Oncogene 2007, 26:7590-7595.

40. Li W, Xie L, He X, Li J, Tu K, Wei L, Wu J, Guo Y, Ma X, Zhang P, Pan Z, Hu X, Zhao Y, Xie H, Jiang G, Chen T, Wang J, Zheng S, Cheng J, Wan D, Yang S, $\mathrm{Li}$ Y, Gu J: Diagnostic and prognostic implications of microRNAs in human hepatocellular carcinoma. Int J Cancer 2008, 123:1616-1622.

41. Willimott S, Wagner SD: miR-125b and miR-155 contribute to BCL2 repression and proliferation in response to CD40 ligand (CD154) in human leukemic B-cells. J Biol Chem 2012, 287:2608-2617.

42. Jiang F, Liu T, He Y, Yan Q, Chen X, Wang H, Wan X: MiR-125b promotes proliferation and migration of type II endometrial carcinoma cells through targeting TP53INP1 tumor suppressor in vitro and in vivo. BMC Cancer 2011, 11:425.

43. Nishida N, Yokobori T, Mimori K, Sudo T, Tanaka F, Shibata K, Ishii H, Doki Y, Kuwano H, Mori M: MicroRNA miR-125b is a prognostic marker in human colorectal cancer. Int J Oncol 2011, 38:1437-1443.

44. Kovar H, Auinger A, Jug G, Aryee D, Zoubek A, Salzer-Kuntschik M, Gadner $\mathrm{H}$ : Narrow spectrum of infrequent p53 mutations and absence of MDM2 amplification in Ewing tumours. Oncogene 1993, 8:2683-2690.

45. Ban J, Bennani-Baiti IM, Kauer M, Schaefer KL, Poremba C, Jug G, Schwentner R, Smrzka O, Muehlbacher K, Aryee DN, Kovar H: EWS-FLI1 suppresses NOTCH-activated p53 in Ewing's sarcoma. Cancer Res 2008, 68:7100-7109

46. Li Y, Tanaka K, Fan X, Nakatani F, Li X, Nakamura T, Takasaki M, Yamamoto S, Iwamoto Y: Inhibition of the transcriptional function of p53 by EWS-Fli1 chimeric protein in Ewing Family Tumors. Cancer Lett 2010, 294:57-65.

47. Zhou M, Liu Z, Zhao Y, Ding Y, Liu H, Xi Y, Xiong W, Li G, Lu J, Fodstad O, Riker Al, Tan M: MicroRNA-125b confers the resistance of breast cancer cells to paclitaxel through suppression of pro-apoptotic $\mathrm{BCl}-2$ antagonist killer 1 (Bak1) expression. J Biol Chem 2010, 285:21496-21507.

48. Leu Jl, Dumont P, Hafey M, Murphy ME, George DL: Mitochondrial p53 activates Bak and causes disruption of a Bak-Mcl1 complex. Nat Cell Biol 2004, 6:443-450.

49. Svoboda M, Izakovicova Holla L, Sefr R, Vrtkova I, Kocakova I, Tichy B, Dvorak $\mathrm{J}$ : Micro-RNAs miR125b and miR137 are frequently upregulated in response to capecitabine chemoradiotherapy of rectal cancer. Int J Oncol 2008, 33:541-547.

50. Li J, Smyth P, Flavin R, Cahill S, Denning K, Aherne S, Guenther SM, O'Leary $\mathrm{J}$, Sheils O: Comparison of miRNA expression patterns using total RNA extracted from matched samples of formalin-fixed paraffin-embedded (FFPE) cells and snap frozen cells. BMC Biotechnol 2007, 7:36.

51. Xi Y, Nakajima G, Gavin E, Morris CG, Kudo K, Hayashi K, Ju J: Systematic analysis of microRNA expression of RNA extracted from fresh frozen and formalin-fixed paraffin-embedded samples. RNA 2007, 13:1668-1674.

52. Kamura S, Matsumoto Y, Fukushi Jl, Fujiwara T, lida K, Okada Y, Iwamoto Y: Basic fibroblast growth factor in the bone microenvironment enhances cell motility and invasion of Ewing's sarcoma family of tumours by activating the FGFR1-PI3K-Rac1 pathway. Br J Cancer 2010, 103:370-381.

53. Fujiwara T, Fukushi J, Yamamoto S, Matsumoto Y, Setsu N, Oda Y, Yamada H, Okada S, Watari K, Ono M, Kuwano M, Kamura S, lida K, Okada Y, Koga M, Iwamoto Y: Macrophage infiltration predicts a poor prognosis for human ewing sarcoma. Am J Pathol 2011, 179:1157-1170.

doi:10.1186/1475-2867-13-21

Cite this article as: lida et al:: miR-125b develops chemoresistance in

Ewing sarcoma/primitive neuroectodermal tumor. Cancer Cell International 2013 13:21.

\section{Submit your next manuscript to BioMed Central and take full advantage of:}

- Convenient online submission

- Thorough peer review

- No space constraints or color figure charges

- Immediate publication on acceptance

- Inclusion in PubMed, CAS, Scopus and Google Scholar

- Research which is freely available for redistribution

Submit your manuscript at www.biomedcentral.com/submit 